\title{
Anterior Pituitary Hormone Deficiency in Subjects with Total and Partial Primary Empty Sella: Do All Cases Need Endocrinological Evaluation?
}

\author{
Total ve Parsiyel Primer Boş Sella Olgularnda Ön Hipofiz Hormon \\ Yetersizliği: Tüm Olgularda Endokrinolojik Değerlendirme Gerekli \\ midir?
}

Sayid Shafi ZUHUR ${ }^{1}$, Idris KUZU ${ }^{1}$, Feyza Yener OZTURKㄹ, Ender UYSAL ${ }^{2}$, Yuksel ALTUNTAS ${ }^{1}$

${ }^{1}$ Sisli Etfal Training and Research Hospital, Department of Endocrinology and Metabolism, Istanbul, Turkey

${ }^{2}$ Sisli Etfal Training and Research Hospital, Department of Radiology, Istanbul, Turkey

Corresponding Author: Sayid Shafi ZUHUR / E-mail: zuhur744@gmail.com

\begin{abstract}
AIM: To compare anterior pituitary functions between subjects with total and partial primary empty sella (PES) and to assess whether all cases with PES need endocrinological evaluation.

MATERIAL and METHODS: Eighty-one subjects with PES (34 total and 47 partial) were included in the study. Basal anterior pituitary and its target hormones were assessed and those with low insulin like growth factor-1 and/or low basal cortisol levels underwent insulin tolerance test (ITT).

RESULTS: $67.4 \%$ of the subjects with total and $14.9 \%$ of those with partial PES had different degrees of hypopituitarism. However, the frequency of hypopituitarism was significantly higher in cases with total PES. The odds ratio (OR) and $95 \%$ confidence interval (Cl) of secondary hypothyroidism, secondary adrenal, growth hormone and gonadotropin deficiency in subjects with total compared to those with partial PES were as follows: $\mathrm{OR}=20.0,95 \% \mathrm{Cl} 4.16-95.9, \mathrm{OR}=2.4,95 \% \mathrm{Cl} 1.34-5.7, \mathrm{OR}=15.3,95 \% \mathrm{Cl} 4.48-52.6$ and $\mathrm{OR}=10.6,95 \% \mathrm{Cl} 3.37-33.5$, respectively.
\end{abstract}

CONCLUSION: A substantial number of subjects with PES, particularly those with total PES, have pituitary hormone deficiency, so regardless of the type of PES, all subjects must be promptly and carefully evaluated for anterior pituitary hormone deficiency.

KEYWORDS: Primary empty sella, Hypopituitarism, Clinical evaluation, MRI

ÖZ

AMAÇ: Bu çalışmada parsiyel ve total primer boş sella (PBS) olguları arasında ön hipofiz fonksiyonları bakımından karşılaştırma yapılması ve tüm olgularda endokrinolojik değerlendirme gerekliliğinin saptanması amaçlanmıştır.

YÖNTEM ve GEREÇLER: PBS tanısı konan 81 olgu (34 total ve 47 parsiyel) çalışmaya dahil edildi. Tüm olguların bazal ön hipofiz ve bunların hedef hormonlarının düzeylerine bakıldı, insülin benzeri büyüme faktörü-1 ve/veya bazal kortizol düzeyi düşük olan olgulara insülin tolerans testi (ITT) uygulandı.

BULGULAR: Total PBS'sı olan olguların \% 67,4'ü ve parsiyel PBS'sı olan olguların \%14,9'unda değişik düzeylerde hipopituitarizm saptandı. Ancak total PBS'sı olan olgularda hipopituitarizm belirgin olarak daha yüksek bulundu. Sekonder hipotiroidizm, sekonder adrenal yetmezlik, büyüme hormonu ve gonadotropin eksikliklerinin total PBS'sı olan olgularda parsiyel PBS'sı olan olgulara kıyasla odds oranları (OR) ve \%95 güven aralıkları (\%95 GA) sırasıyla OR = 20,0; \%95 GA 4,16- 95,9; OR =2,4; \%95 GA 1,34 - 5,7; OR = 15,3; \%95 GA 4,48 - 52,6 ve OR= 10,6; \%95 GA 3,37 - 33,5 bulundu.

SONUÇ: Bu çalışmanın sonuçları özellikle total PBS'sı olan olgular olmak üzere PBS'sı olan olguların önemli bir kısmında değişik düzeylerde hipopituitarizmin varlığını göstermektedir. Bu nedenle PBS'nın tipine bakılmaksızın tüm olgular ön hipofiz hormon yetmezliği bakımından en kısa sürede uygun bir şekilde değerlendirilmelidirler.

ANAHTAR SÖZCÜKLER: Primer boş sella, Hipopituitarizm, Klinik değerlendirme, MRG

\section{INTRODUCTION}

The term empty sella is a neuroradiological finding defined as the herniation of subarachnoid space within the sella turcica, which is often associated with some degree of flattening of the pituitary gland against the sellar floor and stretching of the pituitary stalk $(7,13,15)$. This condition is classified into two groups, primary and secondary empty sella (7). The secondary empty sella is resulting from various pathological conditions including radiotherapy, surgery, vascular, infective, traumatic and autoimmune causes, as well 
as pituitary adenomas undergoing spontaneous regression (3). In contrast, primary empty sella (PES) is unrelated to the above mentioned pathological conditions (3). Radiologically, empty sella is defined as partial when less than $50 \%$ of the sella is filled with cerebrospinal fluid (CSF) and pituitary gland thickness is $\geq 3 \mathrm{~mm}$ (Figure $1 \mathrm{~A}, \mathrm{~B}$ ), or total when more than $50 \%$ of the sella is filled with CSF and the gland thickness is $\leq 2 \mathrm{~mm}$ in diameter $(1,3)$. Although PES is often found incidentally during neuroradiological studies, it could be associated with serious clinical conditions including different degrees of hypopituitarism and neurological deficits $(7,14)$. However, most of the studies evaluating endocrinological aspects of the PES are retrospective and up to date no study has compared the pituitary functions between total and partial PES, despite the opinion that there is no relationship between the pituitary gland thickness and pituitary hormone deficiency (7). Therefore, due to the lack of well-designed studies, an official recommendation has not been made yet. The aim of this cross-sectional study was therefore to compare anterior pituitary functions between subjects with total and partial PES and to assess whether all cases of PES need endocrinological evaluation.

\section{MATERIALS and METHODS}

\section{Patients}

Eighty-one subjects with PES (70 female, 11 male, mean age $49.9 \pm 14.5$ years) who were referred to our center between January 2011 and September 2012 for endocrinological evaluation were enrolled in this study.

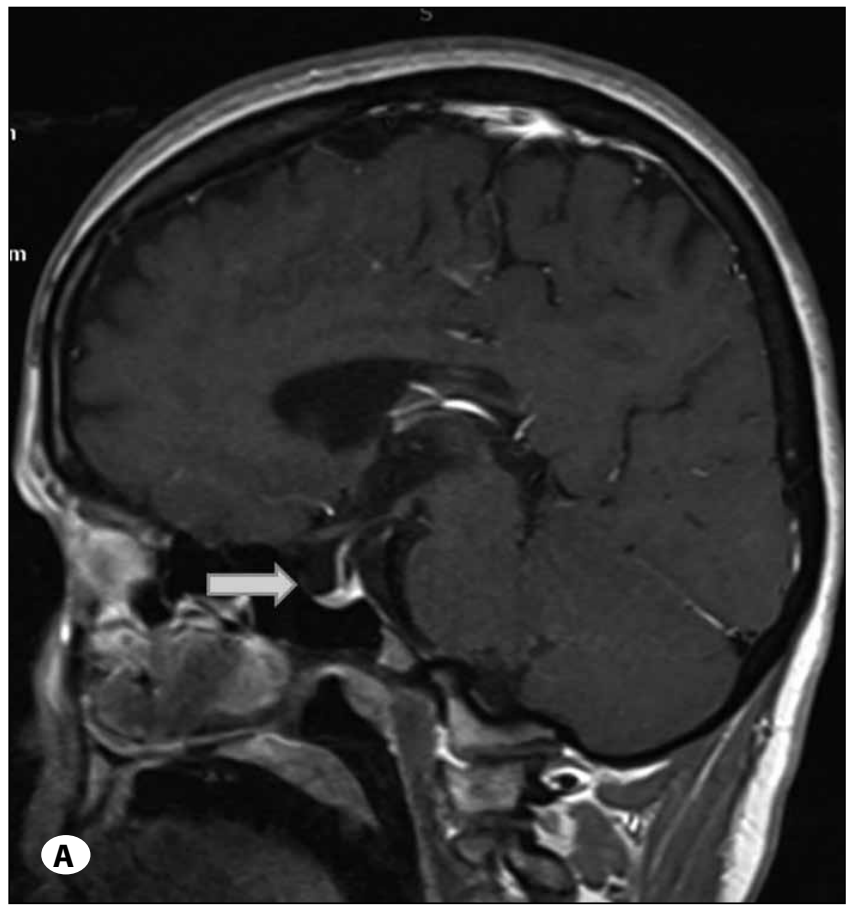

\section{Eligibility Criteria}

Subjects with a previous history of congenital or acquired hypothalamo-pituitary disease, subjects with a previous history of surgery or irradiation to the hypothalamo-pituitary region, subjects with a history of head trauma, subjects with a prolactin level more than $100 \mathrm{ng} / \mathrm{ml}$ in whom the presence of a secondary empty sella due to necrosis of a preexisting prolactinoma could not be ruled out and subjects who were on glucocorticoid or growth hormone $(\mathrm{GH})$ replacement therapy were not included in the study.

\section{Methods}

The anatomical integrity of the hypothalamo-pituitary region of all of the subjects were evaluated by MRI. All MRI's of the subjects were evaluated and/or revised by a radiologist experienced in hypothalamo-pituitary imaging, who were unaware of the laboratory data and clinical condition of the subjects. Partial PES was considered when pituitary thickness was $\geq 3 \mathrm{~mm}$ and $<50 \%$ of the sella was filled with CSF, and total PES was considered when pituitary thickness was $\leq 2$ $\mathrm{mm}$ and $>50 \%$ of the sella was filled with CSF on pituitary MRI (3). All patients with total and partial PES underwent endocrinological evaluation [fasting morning serum samples for $\mathrm{GH}$, insulin like growth factor-1 (IGF-1), FSH, LH, $17 \beta$ estradiol (females), total testosterone (males), cortisol, ACTH, TSH, fT3 and fT4]. Subjects with low age- and gender-matched IGF-1 levels and/or those with low basal serum cortisol levels underwent an insulin-tolerance test (ITT) $(n=31)$. The ITT (regular insulin, Humulin-R, Lilly, USA: 0.1-0.2 U/kg iv) was carried out in the morning after an overnight fast and

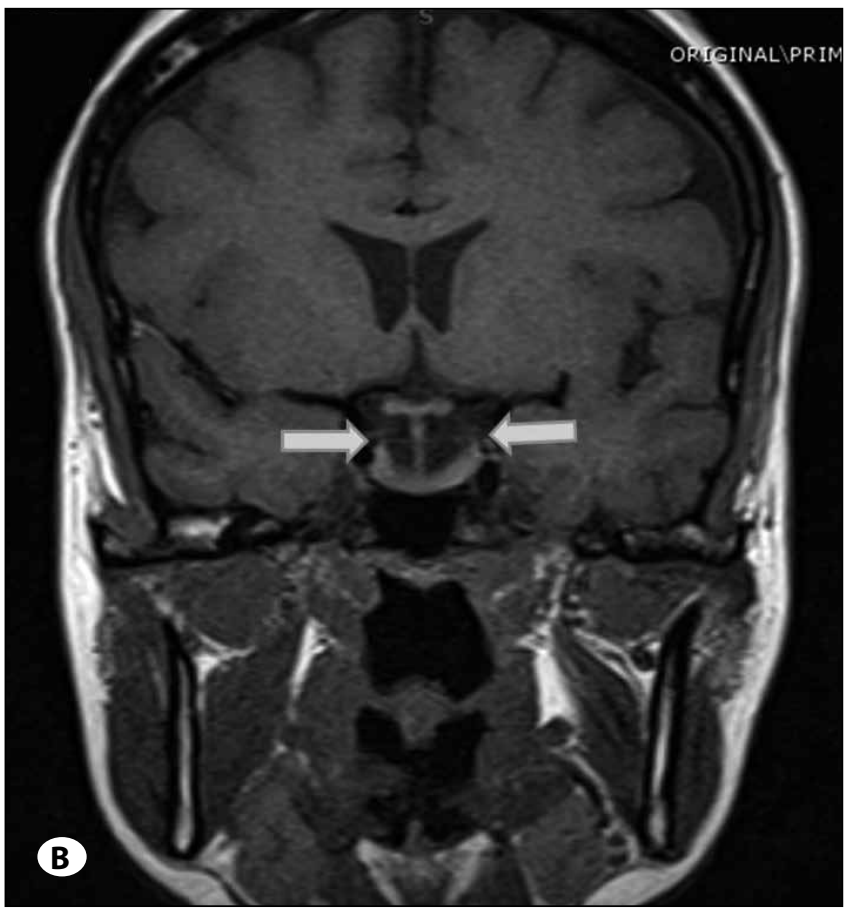

Figure 1: A) T1-weighted sagittal section MRI and B) T1-weighted coronal section MRI of a patient with partial primary empty sella. 
blood samples were taken every $15 \mathrm{~min}$ from 0 to $90 \mathrm{~min}$ to determine serum $\mathrm{GH}$ and cortisol assays, after falling of plasma glucose below $40 \mathrm{mg} / \mathrm{dL}(2.2 \mathrm{mmol} / \mathrm{L})(5,17)$. According to this test, serum $\mathrm{GH}$ level $\geq 5,1 \mu \mathrm{g} / \mathrm{L}$ (the level recommended by the Endocrine Society clinical practice guideline 2011) (17) and cortisol level $>20 \mu \mathrm{g} / \mathrm{dL}(550 \mathrm{nmol} / \mathrm{L})$ were considered as a normal response (5). Serum prolactin levels on 0,15 , 30 and 45 minutes were obtained on a different day from subjects with prolactin levels above the reference laboratory values with the patient recumbent to account for possible prolactin pulsatility and prolactin levels above the reference laboratory ranges in both 30 and 45 minutes were considered as hyperprolactinemia (16). Other stimulation tests [TRH (TRH, Ferring, Germany), $200 \mu \mathrm{g}$ iv bolus injection with blood samples for determination of TSH levels taken at $-15,0,20$, 40, and 60 minutes (7); and GnRH (LH-RH, Ferring, Germany), $100 \mu \mathrm{g}$ iv bolus injection with serum samples for LH and FSH assays taken at $-15,0,15,30,45,60,90$, and 120 minutes (8)] were carried out when secondary hypothyroidism and gonadotropin deficiency were suspected. Body mass index (BMI) was calculated as the weight in kilograms divided by the height in meters squared.

Serum prolactin, $\mathrm{FSH}, \mathrm{LH}$, cortisol, $17 \beta$ estradiol and total testosterone levels were measured by an electrochemiluminescence immunoassay method on Elecsys and cobas immunoassay analyzers (Roche Diagnostics $\mathrm{GmbH}$, Mannheim, Germany), serum TSH, fT3 and fT4 were assessed using a direct chemiluminescence immunoassay method (Siemens, ADVIA Centaur XP Immunoassay System, Tarrytown, NY, USA) and Serum GH, IGF-1, ACTH and total testosterone levels were measured by Immulite 2000 assay (Siemens AG).

An informed consent was obtained from all participants and the study protocol was approved by the Sisli Etfal Training and Research Hospital ethics committee.

\section{Statistical Analysis}

An SPSS (statistical package for social sciences, for Windows, release 15.0.0, standard version) program was used for statistical evaluations. Data were expressed as mean \pm standard deviation. The categorical data were assessed by the Pearson chi-square test. Student's t and Fisher's exact tests were used for the comparison of parametric quantitative data. Regression analysis was used to estimate the odds ratio (OR) and $95 \%$ confidence interval $(95 \% \mathrm{Cl})$ of individual pituitary hormone deficiency between subjects with total and partial PES.

\section{RESULTS}

The participants' characteristics and baseline biochemical features are summarized in Table I. The mean age, BMI and the frequency of comorbid diseases such as obesity, type 2 DM and hypertension were not different between subjects with total and partial PES.

In the present study, $5(14.7 \%)$ of the subjects with total PES had 1, 1 (2.9\%) had 2, 3 (8.8\%) had 3, and $14(41 \%)$ had more than 3 pituitary hormone deficiency or global anterior hypopituitarism, whereas $3(6.4 \%)$ of the subjects with partial PES had 1, $2(4.3 \%)$ had 2, $1(2.1 \%)$ had 3 and only $1(2.1 \%)$ had more than 3 pituitary hormone deficiency. Eleven $(32.5 \%)$ of the subjects with total and $40(85 \%)$ of the subjects with partial PES had no pituitary hormone deficiency.

Based on the hormonal evaluation carried out after appropriate stimulation tests, secondary hypothyroidism, secondary adrenal deficiency, GH and gonadotropin deficiency were significantly higher in subjects with total compared to those with partial PES (Table II). The odds ratio (OR) and 95\% confidence intervals $(\mathrm{Cl})$ of secondary hypothyroidism, secondary adrenal deficiency, GH and gonadotropin deficiency in subjects with total compared to those with partial PES were as follows: $\mathrm{OR}=20.0,95 \% \mathrm{Cl} 4.16-95.9, \mathrm{OR}$ $=2.4,95 \% \mathrm{Cl} 1.34-5.7, \mathrm{OR}=15.3,95 \% \mathrm{Cl} 4.48-52.6$ and $\mathrm{OR}=10.6,95 \% \mathrm{Cl} 3.37-33.5$, respectively. As demonstrated in Table II, GH and gonadotropin deficiency were more frequent than other pituitary hormone deficiencies, whereas secondary adrenal deficiency was less frequent than other pituitary hormone deficiencies in subjects with total and partial PES. However, the frequency of hyperprolactinemia was not different between the two groups of the participants.

Furthermore, we analysed the causes of admission of the subjects with total and partial PES. Accordingly, the main complaint during admission to the hospital was also different between the 2 groups of the participants. Twenty two (47 $\%)$ of the subjects with partial and 12 (35\%) with total PES admitted with headache to the hospital. However, other accompanying complaints of the subjects with total PES at admission to the hospital was nonspecific symptoms due to the disruption of different pituitary hormones, either isolated or in combination such as fatigue, dizziness, syncope, loss of appetite, arthralgia, myalgia, nausea and weight loss. Although a small number of female subjects were premenopausal, 1 (2\%) woman with partial PES admitted with amenorrhea and mild galactorrhea, whereas 3 (9\%) women with total PES admitted to the hospital just with secondary amenorrhea due to gonadotropin deficiency. On the other hand, $1(2.1 \%)$ male subject with partial PES and 1 (3\%) with total PES were admitted with erectile dysfunction and infertility due to gonadotropin deficiency. One female subject with total PES had isolated secondary adrenal deficiency. However, none of the subjects with total or partial PES had diabetes insipidus, CSF rhinorrhea or visual complaints.

\section{DISCUSSION}

The widespread use of neuroimaging in daily practice, particularly MRI, has made PES a frequent incidental finding. On the other hand, patients may also apply to the hospital with CSF rhinorrhea, severe intracranial hypertension and visual deficits, as well as different degrees of hypopituitarism (7). Isolated or multiple pituitary hormone deficiencies has been suggested to be present in $8-60 \%$ of cases of PES (6). As mentioned in results section, $67,4 \%$ of the subjects with total and $14.9 \%$ of those with partial PES in this study had different 
degrees of hypopituitarism, suggesting the high frequency of anterior pituitary hormone deficits in these subjects. Therefore, the prompt endocrinological evaluation of these patients is extremely important, regardless of the type of PES on neuroimaging studies.

Several mechanisms including incomplete formation of diaphragma sellae, suprasellar causes such as intermittent or constant increase in intracranial pressure have been claimed in the development of PES $(7,11)$. Studies have also demonstrated a clear relationship between obesity and PES (12). Studies also suggest chronic CSF hypertension caused by hypercapnia in morbidly obese subjects. This CSF hypertension induces the herniation of subarachnoid space into the sellar fossa (4). In the current study $73.5 \%$ of the subjects with total and $76.5 \%$ of those with partial PES were overweight or obese, demonstrated as BMI $>25 \mathrm{Kg} / \mathrm{m}^{2}$. In concordance with previous reports (12), results from the present study also suggest a clear relationship between obesity and PES.

Pregnancy may contribute to the development of PES. The pituitary volume increases during pregnancy (10). This pituitary volume enlargement may result in herniation of the subarachnoid space into the sellar fossa, especially in cases with high CSF pressure (7). Our data are substantially in line with what is reported in the literature and displayed that more than $70 \%$ of women either with total or partial

Table I: Baseline Clinical and Biochemical Characteristics of the Study Participants

\begin{tabular}{|c|c|c|c|c|}
\hline & All Participants ( $n=81$ ) & Partial PES (n=47) & Total PES $(n=34)$ & p-value \\
\hline Age & $49.9 \pm 14.5$ & $49.9 \pm 15.8$ & $49.9 \pm 12.5$ & 0.97 \\
\hline Female & $70(86.4 \%)$ & $38(81 \%)$ & 32 (94\%) & - \\
\hline Male & $11(13.6 \%)$ & $9(19 \%)$ & $2(6.0 \%)$ & - \\
\hline Multiparity & $59(73 \%)$ & $34(72.4 \%)$ & $25(73.5 \%)$ & 0.49 \\
\hline BMI & $29.2 \pm 6.08$ & $29.5 \pm 5.63$ & $28.9 \pm 6.72$ & 0.67 \\
\hline Hypertension & $20(24.7 \%)$ & $20(25.5 \%)$ & $8(23.5 \%)$ & 0.52 \\
\hline Type 2 DM & $9(11.1 \%)$ & $5(10.6 \%)$ & $4(12.0 \%)$ & 0.57 \\
\hline Prolactin & $16.6 \pm 20.3$ & $16.1 \pm 18.6$ & $17.3 \pm 22.7$ & 0.80 \\
\hline Growth hormone & $0.72 \pm 1.52$ & $0.77 \pm 1.32$ & $0.66 \pm 1.78$ & 0.74 \\
\hline IGF-1* & $120.7 \pm 76.1$ & $151.5 \pm 72.3$ & $78.2 \pm 59.5$ & $<0.001$ \\
\hline FSH & $22.0 \pm 26.1$ & $24.4 \pm 27.5$ & $18.7 \pm 24.1$ & 0.33 \\
\hline $\mathrm{LH}$ & $13.3 \pm 13.9$ & $15.3 \pm 14.5$ & $10.6 \pm 12.9$ & 0.14 \\
\hline $17 \beta$ estradiol ${ }^{* *}$ & $58.9 \pm 108.3$ & $84.1 \pm 111.9$ & $29.0 \pm 97.3$ & 0.03 \\
\hline Total testosteroneף & $254.9 \pm 152.1$ & $295.0 \pm 135.0$ & $74.5 \pm 77.0$ & $<0.001$ \\
\hline Cortisol & $11.8 \pm 5.98$ & $14.3 \pm 3.92$ & $8.41 \pm 6.65$ & $<0.001$ \\
\hline ACTH & $18.1 \pm 10.2$ & $20.0 \pm 9.40$ & $15.5 \pm 10.9$ & 0.049 \\
\hline TSH & $2.19 \pm 1.35$ & $2.39 \pm 1.20$ & $1.91 \pm 1.50$ & 0.11 \\
\hline fT3 & $2.73 \pm 0.75$ & $2.96 \pm 0.44$ & $2.41 \pm 0.95$ & 0.001 \\
\hline fT4 & $0.93 \pm 0.39$ & $1.07 \pm 0.20$ & $0.75 \pm 0.51$ & 0.001 \\
\hline
\end{tabular}

*: Matched for age and gender. **: in female subjects. ף: in male subjects. PES: primary empty sella. BMI: body mass index. DM: diabetes mellitus. IGF-1: insulin like growth factor-1. Normal laboratory reference ranges: $P R L$ (6-29.9 ng/mL), GH (0-8 ng/mL), FSH (25.8-134.8 IU/mL), LH (7.7-59 IU/mL), $17 \beta$ estradiol (5-54.7 pg/mL), total testosterone (241-827 ng/dL), cortisol (6.2-19.4 $\mathrm{gg} / \mathrm{dL})$, ACTH (0-46 pg/mL), TSH (0.27-4.2 $\mu \mathrm{lU} / \mathrm{mL})$, fT3 (1.96-4.36 pg/mL), fT4 (0.72-1.56 $n g / d L)$.

Table II: The Comparison of Hyperprolactinemia, Secondary Hypothyroidism, Hypogonadism, Adrenal Insufficiency and GH Deficiency Between Subjects with Total and Those with Partial PES

\begin{tabular}{|c|c|c|c|c|}
\hline & All Participants ( $n=81)$ & Partial PES ( $n=47)$ & Total PES $(n=34)$ & p-value \\
\hline Hyperprolactinemia & $13(16.0 \%)$ & $7(15.0 \%)$ & $6(17.6 \%)$ & 0.48 \\
\hline Hypothyroidism* & $18(22.2 \%)$ & $2(4.3 \%)$ & $16(47.1 \%)$ & $<0.001$ \\
\hline Gonadotropin deficiency & $24(29.6 \%)$ & $5(10.6 \%)$ & $19(55.9 \%)$ & $<0.001$ \\
\hline GH deficiency & $24(29.6 \%)$ & $4(8.5 \%)$ & $20(58.8 \%)$ & $<0.001$ \\
\hline Adrenal insufficiency* & $7(8.6 \%)$ & $2(4.3 \%)$ & $5(14.7 \%)$ & $<0.001$ \\
\hline
\end{tabular}

*: secondary, GH: growth hormone, PES: primary empty sella. 
PES were multiparous. As in previous reports (12), our results also demonstrate that multiparity may contribute to the development of PES.

Visual disturbances including bitemporal hemianopsia and decreasing visual acuity which are resulting from herniation of the optic nerve, were reported in $1.6-16 \%$ of patients with PES (11). However, visual defects were not found on ophthalmological evaluation of the subjects and visual defects were not the presenting symptom of the subjects enrolled in our study. Nevertheless, it should be emphasized that ophthalmological evaluation was carried out only in 20 cases with total PES. Therefore, we could not determine the actual frequency of visual defects in the participants of this study.

Serum prolactin levels may be increased in about $10-37.5 \%$ of subjects with PES $(2,3,4,7,12)$. Hyperprolactinemia is resulting from compression of pituitary stalk by $\operatorname{CSF}(3,7,12)$. However if the prolactin levels are more than $100 \mathrm{ng} / \mathrm{mL}$, the presence of a prolactinoma should be considered (3). In this study $17.6 \%$ of subjects with total and $15 \%$ of those with partial PES had high prolactin levels and none of the cases had prolactin levels more than $100 \mathrm{ng} / \mathrm{mL}$. However, no difference was observed in terms of hyperprolactinemia between subjects with total and those with partial PES. Although hyperprolactinemia has been proposed as the most common endocrinological dysfunction in patients with PES $(4,12)$, our results are not consistent with this argument, since the GH deficiency was the most common endocrine dysfunction in our study. This inconsistency may be related to the evaluation of patients for hyperprolactinemia with serial prolactin measurements on a different day to account for possible prolactin pulsatility and venipuncture stress, which was not performed in previous studies.

Studies demonstrated different degrees of hypopituitarism in about $8-60 \%$ of cases with PES and GH/IGF-1 axis being the most common affected axis $(6,18)$. Evidence suggested that growth hormone deficiency (GHD) was present in $60 \%$ of cases with PES (4.6). Delmonti et al. suggested lower response of $\mathrm{GH}$ to $\mathrm{GHRH}$ plus arginine in a substantial number of patients with intact other anterior pituitary hormones (4). However, no study has evaluated the frequency of GHD in subjects with total compared to those with partial PES. In the present study, GHD was present in 59\% of subjects with total and $8.5 \%$ of those with partial PES, either isolated or in combination with other anterior pituitary hormone deficiencies. The OR and $95 \% \mathrm{Cl}$ of GHD in subjects with total compared to those with partial PES were 15.3 and 4.48 - 52.6, respectively. Taking in consideration the adverse effects of GHD on the cardiovascular system and general well being, the evaluation of $\mathrm{GH} / \mathrm{IGF}-1$ axis in patients with PES is important.

Gonadotropin deficiency was reported in $6 \%$ of cases of PES (7). However, in the current study, the frequency of gonadotropin deficiency was more common compared to the previous reports and similar to the GHD, it was more common in subjects with total compared to those with partial PES (OR= $10.6,95 \% \mathrm{Cl} 3.37$ - 33.5). Other pituitary hormone deficiencies such as secondary hypothyroidism and adrenal insufficiency were also higher then previously reported $(3,12)$ and they were also significantly higher in cases with total compared to the cases with partial PES (OR $=20.0,95 \% \mathrm{Cl} 4.16$ - 95.9, OR $=2.4,95 \% \mathrm{Cl} 1.34-5.7$, respectively). The reason for the high frequency of secondary hypothyroidism, secondary adrenal insufficiency and gonadotropin deficiency in this study may be related to different factors such as the design of this study, the age of the participants which could be an indirect indicator of duration of the disease and to the dynamic tests which were carried out in any suspected patient for secondary hypothyroidism, adrenal and gonadotropin deficiency. Although previous studies indicated that hypopituitarism was not related to the size of pituitary gland in cases with PES (7), our results demonstrated that the size of the residual pituitary gland is an important determinant of hypopituitarism in cases with PES. Our results indicate that some degree of hypopituitarism is present in two thirds of the cases with total and is less frequent than previously thought in cases with partial PES. However, because anterior pituitary hormone deficiencies could also be present in an important number of cases with partial PES, all of the cases with PES should be properly evaluated by appropriate endocrinological tests for the presence of pituitary hormone deficiencies.

This study has several limitations. At first, ITT for the evaluation of GH deficiency were not performed in all of the participants. Therefore, it was not possible to determine the actual frequency of GH deficiency in participants of this study. The second limitation is the cross sectional design of this study, so we could not evaluate the clinical course and development of further pituitary hormone deficiency in subjects with normal pituitary functions at presentation, and finally, as mentioned before, the ophthalmological evaluation was just carried out in 20 cases with total PES. Therefore, we could not determine the actual frequency of visual defects in the participants of this study. However, this is the first study comparing the clinical and biochemical aspects between subjects with total and partial PES.

In conclusion, results from this study suggest a substantial number of subjects with PES, particularly those with total PES, have different degrees of pituitary hormone deficiency. So regardless of the type of PES on neuroimaging studies or its clinical presentation, all subjects with PES must be promptly and carefully evaluated for anterior pituitary hormone deficiency and therefore, by appropriate replacement of deficient hormones, long-term complications of pituitary hormone deficiencies could be prevented.

\section{REFERENCES}

1. Bensing $S$, Rorsman F, Crock $P$, Sanjeevi C, Ericson $K$, Kampe O, Brismar K, Hulting AL: No evidence for autoimmunity as a major cause of the empty sella syndrome. Exp Clin Endocrinol Diabetes 112:231-235,2004 
2. Cannavo $S$, Curto $L$, Venturino $M$, Squadrito $S$, Almoto B, Narbonne MC, Rao R, Trimarchi F: Abnormalities of hypothalamic-pituitary-thyroid axis in patients with primary empty sella. J Clin Endocrinol Metab 25(3):236-239,2002

3. De Marinis L, Bonadonna S, Bianchi A, Maira G, Giustina A: Primary empty sella. J Clin Endocrinol Metab 90(9): 5471-5477,2005

4. Del Monte P, Foppiani L, Cafferata C, Rattles A, Bernasconi D: Primary "empty sella": In adults: Endocrine findings. Endocr J 53(6):803-809,2006

5. Dokmetas HS, Colak R, Kelestimur F, Selcuklu A, Unluhizarci $\mathrm{K}$, Bayram F: A comparison between the 1-microg adrenocorticotropin (ACTH) test, the short ACTH (250 microg) test, and the insulin tolerance test in the assessment of hypothalamopituitary-adrenal axis immediately after pituitary surgery. J Clin Endocrinol Metab 85(10):3713-3719,2000

6. Gasperi M, Aimaretti G, Cecconi E, Colao A, Di Somma C, Cannavò $S$, Baffoni $C$, Cosottini $M$, Curtò $L$, Trimarchi $F$, Lombardi G, Grasso L, Ghigo E, Martino E: Impairment of GH secretion in adults with primary empty sella. J Endocrinol Invest 25(4):329-333,2002

7. Giustina A, Aimaretti G, Bondanelli M, Buzi F, Cannavò S, Cirillo S, Colao A, De Marinis L, Ferone D,Gasperi M, Grottoli S, Porcelli T, Ghigo E, degli Uberti E: Primary empty sella: Why and when to investigate hypothalamic-pituitary function. J Endocrinol Invest 33(5):343-346,2010

8. Giustina A, Bossoni S, Buffoli MG, Ferrari C, Pozzi A, Scalvini T, Schettino M: Effect of pretreatment with pyridostigmine on the thyrotropin response to thyrotropin-releasing hormone in patients with Cushing's disease. Horm Metab Res 24: 248-250,1992

9. Giustina A, Scalvini T, Cerudelli B, Bossoni S, Bodini C, Orlandini A, Romanelli G: Hypopituitarism secondary to suprasellar giant carotido- ophthalmic aneurysm. Normalization of the hypophyseal function after neurosurgical depression of the aneurysm. Minerva Endocrinol 14:255-258,1989
10. Gonzalez JG, Elizondo G, Saldivar D: Pituitary gland growth normal during pregnancy: An in vivo study using magnetic resonance imaging. Am J Med 85:217-220,1988

11. Guinto G, Mercado M, Abdo M, Nishimura E, Arechiga N, Nettel B: Primary empty sella syndrome. Contemp Neurosurg 29(11):1-6,2007

12. Guitelman M, Garcia Basavilbaso N, Vitale $M$, Chervin A, Katz D, Miragaya K, Herrera J, Cornalo D, Servidio M, Boero L, Manavela M, Danilowicz K, Alfieri A, Stalldecker G, Glerean M, Fainstein Day P, Ballarino C, Mallea Gil MS, Rogozinski A: Primary empty sella (PES): A review of 175 cases. Pituitary 16(2):270-274,2013

13. Jordan RM, Kendall JW, Kerber CW: The primary empty sella syndrome: Analysis of the clinical characteristic, radiographic features, pituitary function and cerebral fluid adenohypophysial concentrations. Am J Med 62:569-580,1977

14. Komada H, Yamamoto M, Okubo S, Nagai K, lida K, Nakamura T, Hirota Y, Sakaguchi K, Kasuga M, Takahashi Y: A case of hypothalamic panhypopituitarism with empty sella syndrome: Case report and review of the literature. Endocr J 56(4):585-589,2009

15. McLachlan MSF, Williams ED, Doyle FH: Applied anatomy of the pituitary gland and fossa: $A$ radiological and histopathological study based on 50 necropsies. $\mathrm{Br} J$ Radiol 41:782-788, 1968

16. Melmed S, Casanueva FF, Hoffman AR, Kleinberg DL, Montori VM, Schlechte JA, Wass JAH: Diagnosis and treatment of hyperprolactinemia: An endocrine society clinical practice guideline. J Clin Endocrinol Metab 96: 273-288,2011

17. Molitch ME, Clemmons DR, Malozowski S, Merriam GR, Vance ML: Evaluation and treatment of adult growth hormone deficiency: An Endocrine Society Clinical Practice Guideline. J Clin Endocrinol Metab 96(6):1587-1609,2011

18. Poggi M, Monti S, Lauri C, Pascucci C, Bisogni V, Toscano V: Primary empty sella and GH deficiency: Prevalence and clinical implications. Ann Ist Sanita 48(1):91-96,2012 